\title{
THE EFFECTIVENESS OF INTERNATIONAL TEACHING PRACTICE PROGRAM: PERCEPTIONS FROM MALAYSIAN AND INDONESIAN TRAINEE TEACHERS
}

\author{
Nur Hazirah Noh@Seth*, Dayana Farzeeha Ali, Mohd Ali Ibrahim, Nur Husna Abd Wahid, Mohamad \\ Rasidi Pairan, Muhamad Eizanie Muhamad \\ School of Education, Faculty of Social Sciences and Humanities, Universiti Teknologi Malaysia, 81310 \\ Skudai, Johor, Malaysia \\ *nurhazirah.n@utm.my
}

\begin{abstract}
The aim of this research is to evaluate the trainee teachers' perception on the effectiveness of the international teaching practice program implemented by various international public higher institutions. The research questions cover the aspect of generic skills inclusive of communication skills, teamwork skills, and problem solving skills, together with the aspect of lesson plans, attitudes, and knowledge. 70 fourth year students from UTM, UNY, UPGRI Semarang, and UNIMUSH Makassar were randomly selected as the sample of this research. The data were analysed using descriptive analysis such as frequencies, percentages, mean, and T-test at 0.05 level of significance. Overall findings show that both Malaysian and Indonesian trainee teachers' perceptions retained at high level during the international teaching practice program. They also recorded positive perceptions on generic skills $($ mean $=4.14$ (Malaysian); mean $=4.09$ (Indonesian)), trainee teachers' lesson plan $($ mean $=4.12$ (Malaysian); mean $=4.14$ (Indonesian) $)$, trainee teachers' attitude $($ mean $=4.12$ (Malaysian); mean $=4.16$ (Indonesian)), and trainee teachers' knowledge (mean $=4.19$ (Malaysian); mean $=4.15$ (Indonesian)). Future recommendations are also included to improve the program in the near future.
\end{abstract}

Keywords: Teaching Practice, Generic Skills, Trainee Teacher, Lesson Plan

\section{INTRODUCTION}

Teaching profession is an important profession in the development of human, society, and nation. It is among the main profession in knowledge transfer to individuals and societies to upbringing future leaders who will continue the legacy to rein the country. In the globalisation era, the role of teachers is getting more complex and challenging. Their responsibilities are not limited to only teaching according to the class schedule provided by the school's management, but they also act as the agents to provide the effectiveness of education to the nation. To strengthen the teaching profession, teaching practice program has been introduced to the institutions involved with the aim in providing the chance to the trainees teacher to apply all the concepts, principles, skills, and values learned in the real school context. Through this program, trainee teachers could practice the theory of teaching and learning learned at their institutions to train the trainees in becoming high quality teacher with outstanding knowledge and skills in practicing the teaching principles in accordance with National Education Philosophy. The teaching practice program conducted at the university level in Malaysia is a practice for the trainee teachers in the stipulated time given to gain the experience teaching in the real classroom at school. The program is conducted with the hoping that the future teachers will realise their responsibility and current demand, especially in upbringing them to be efficient and dedicated to the tasks given (Ahmad, 2010).

The effectiveness in generic skills can be enhanced when the trainee teachers are confidents in their communication, especially during the teaching and learning process in the class or even with other teachers in the school. Meanwhile, the team working skills could be improved by working together to complete the task given with other teachers. At the same time, they could also actualised the theoretical and practical skills learned during the entire teaching practice program. They could also enhanced their 
knowledge based on the teaching and learning activities at school, simultaneously change their attitude towards a better and positive attitude. Hence, the researchers took the initiative in finding the effectiveness of international teaching practice program (Malaysia and Indonesia) in training the trainee teachers to be skilled and capable teacher in various aspects.

\section{Objectives}

This research was conducted to gain the response from Malaysian and Indonesian trainee teachers on the effectiveness of international teaching practice program (Malaysia and Indonesia) covering the aspects of generic skills (communication skills, team working skills, problem solving skills), lesson plan, attitude, and knowledge based on the following objectives:

1. To identify the trainee teachers' perception on the effectiveness of international teaching practice program from the aspects of generic skills including communication skills, team working skills, and problem solving skills

2. To identify the trainee teachers' perception on the effectiveness of international teaching practice program from the aspects of lesson plan

3. To identify the trainee teachers' perception on the effectiveness of international teaching practice program from the aspects of attitude

4. To identify the trainee teachers' perception on the effectiveness of international teaching practice program from the aspects of content knowledge.

\section{METHODOLOGY}

The study uses descriptive survey method, where according to Mohd (2003), questionnaire is appropriately used to gain the information related to facts, feelings, and needs. The survey method is used to collect the information, perception, and opinion of trainee teachers in Malaysia and Indonesia on the international teaching practice program. The survey was measured through four aspects, namely the generic skills, lesson plan, attitude, and knowledge of the trainee teachers. Two groups of population were involved in this study, where all respondents were selected among those who had involved with the international teaching practice program. The first group are the trainee teachers in Year 4 (the eighth semester 2014/2015) from the School of Education, Universiti Teknologi Malaysia. Meanwhile, the second group consists of trainee teachers from Universitas Negeri Yogyakarta (UNY), Universitas PGRI Semarang, Universitas Negeri Makassar (UNM), and Universitas Muhammadiyah Makassar (UNISMUH), all from Indonesia. Table 1 shows the tabulated population in this study.

Table 1. Tabulated population

\begin{tabular}{|c|c|c|}
\hline No & University & Population (Teacher Trainees) \\
\hline 1 & Universiti Teknologi Malaysia (UTM) & 38 \\
\hline 2 & Universitas Negeri Yogyakarta (UNY) & 10 \\
\hline 3 & Universitas PGRI Semarang (UPGRI Semarang) & 14 \\
\hline 4 & Universitas Muhammadiyah Makassar (UNISMUH) & 14 \\
\hline 5 & Universitas Negeri Makassar (UNM) & 10 \\
\hline & Total & 86 \\
\hline
\end{tabular}

86 trainee teachers from all 5 universities involved were selected, and only 70 were selected as the research sample. This value is calculated based on the table by Krejcie and Morgan (1970). These 70 trainee teachers were then separated into two groups, 35 of them from UTM and the remaining 35 from all universities in Indonesia. The instrument used in this study is questionnaire, circulated among the respondents to gain their responses. This is because, the respondents are more reluctant in responding to the aspects investigated in the research compared to through interview method. The survey method is easier and could save a lot of time and cost. The questionnaire was designed based on the objectives of the research, divided into two main parts which are part A and part B. 
According to Mohd (2003), a pilot study is conducted to measure the validity and verify the items in the questionnaire before the actual study is conducted. Pilot study is also used to find the problem that might arise during data collection. In this research, a pilot study was conducted involving 15 respondents from the fourth year student of the School of Education UTM who had involved with the international teaching practice program. A total of 15 respondents is sufficient to analysethe internal validity and reliability index. The Cronbach's Alpha which represents the reliability of the items built in the instrument used was obtained through the analysis of 15 instruments collected from the pilot study using the Statistical Package for Social Science (SPSS) software version 16.0. From the pilot study, the value of reliability for the instrument circulated is $\alpha=0.94$, exceeding the value of reliability coefficient of 0.60 . Hence, the items in the instrument are proven to have high internal consistency Mohd (2003).

\section{RESULTS AND DISCUSSION}

\section{T-Test Analysis for Research Question 1}

Table 2. T-test analysis on the effectiveness of international teaching practice program from the aspect of communication skills based on the trainee teachers

\begin{tabular}{|c|c|c|c|c|c|}
\hline Trainee Teacher & Total & Mean & Standard Deviation & T-value & Significance Level \\
\hline Malaysia & 35 & 4.084 & 0.297 & 0.276 & 0.790 \\
\hline Indonesia & 35 & 4.124 & 0.130 & & \\
\hline
\end{tabular}

The hypothesis is as follows:

H01: There is no significant difference between Malaysian and Indonesian trainee teachers' perception on the effectiveness of international teaching practice program from the aspects of communication skills

Table 2 shows that the t-value for the comparison of communication skills aspect between Malaysian and Indonesian trainee teachers in international teaching practice is $t=0.276$, with the level of significance, $p=0.790$. This value exceed the threshold value of $0.05(p>0.05)$, hence null hypothesis is accepted where there is no significant difference between Malaysian and Indonesian trainee teachers' perception on the effectiveness of international teaching practice program from the aspects of communication skills.

Table 3. T-test analysis on the effectiveness of international teaching practice program from the aspect of team working skills based on the trainee teachers

\begin{tabular}{|c|c|c|c|c|l|}
\hline Trainee Teacher & Total & Mean & Standard Deviation & T-value & Significance Level \\
\hline Malaysia & 35 & 4.246 & 0.185 & 0.233 & 0.822 \\
\hline Indonesia & 35 & 4.190 & 0.211 & & \\
\hline
\end{tabular}

The hypothesis is as follows:

H01: There is no significant difference between Malaysian and Indonesian trainee teachers' perception on the effectiveness of international teaching practice program from the aspects of team working skills

Table 3 shows that the t-value for the comparison of team working skills aspect between Malaysian and Indonesian trainee teachers in international teaching practice is $t=0.233$, with the level of significance, $p=0.822$. This value exceed the threshold value of $0.05(p>0.05)$, hence null hypothesis is accepted where there is no significant difference between Malaysian and Indonesian trainee teachers' perception on the effectiveness of international teaching practice program from the aspects of team working skills. 
Table 4. T-test analysis on the effectiveness of international teaching practice program from the aspect of problem solving skills based on the trainee teachers

\begin{tabular}{|c|c|c|c|c|c|}
\hline Trainee Teacher & Total & Mean & Standard Deviation & T-value & Significance Level \\
\hline Malaysia & 35 & 4.02 & 0.236 & 1.476 & 0.178 \\
\hline Indonesia & 35 & 3.91 & 0.137 & & \\
\hline
\end{tabular}

The hypothesis is as follows:

H01: There is no significant difference between Malaysian and Indonesian trainee teachers' perception on the effectiveness of international teaching practice program from the aspects of problem solving skills

Table 4 shows that the t-value for the comparison of problem solving skills aspect between Malaysian and Indonesian trainee teachers in international teaching practice is $t=1.476$, with the level of significance, $p=0.178$. This value exceed the threshold value of $0.05(p>0.05)$, hence null hypothesis is accepted where there is no significant difference between Malaysian and Indonesian trainee teachers' perception on the effectiveness of international teaching practice program from the aspects of problem solving skills.

\section{T-Test Analysis for Research Question 2}

Table 5. T-test analysis on the effectiveness of international teaching practice program from the aspect of lesson plan based on the trainee teachers.

\begin{tabular}{|c|c|c|c|c|c|}
\hline Trainee Teacher & Total & Mean & Standard Deviation & T-value & Significance Level \\
\hline Malaysia & 35 & 4.122 & 0.102 & -0.208 & 0.841 \\
\hline Indonesia & 35 & 4.136 & 0.111 & & \\
\hline
\end{tabular}

The hypothesis is as follows:

H02: There is no significant difference between Malaysian and Indonesian trainee teachers' perception on the effectiveness of international teaching practice program from the aspects of lesson plan

Table 5 shows that the t-value for the comparison of lesson plan aspect between Malaysian and Indonesian trainee teachers in international teaching practice is $\mathrm{t}=0.208$, with the level of significance, $p=0.841$. This value exceed the threshold value of $0.05(p>0.05)$, hence null hypothesis (H02) is accepted where there is no significant difference between Malaysian and Indonesian trainee teachers' perception on the effectiveness of international teaching practice program from the aspects of lesson plan.

\section{T-Test Analysis for Research Question 3}

Table 6. T-test analysis on the effectiveness of international teaching practice program from the aspect of attitude based on the trainee teachers

\begin{tabular}{|c|c|c|c|c|c|}
\hline Trainee Teacher & Total & Mean & Standard Deviation & T-value & Significance Level \\
\hline Malaysia & 35 & 4.120 & 0.114 & -0.381 & 0.713 \\
\hline Indonesia & 35 & 4.160 & 0.205 & & \\
\hline
\end{tabular}

The hypothesis is as follows:

H03: There is no significant difference between Malaysian and Indonesian trainee teachers' perception on the effectiveness of international teaching practice program from the aspects of attitude 
Table 6 shows that the t-value for the comparison of attitude aspect between Malaysian and Indonesian trainee teachers in international teaching practice is $t=0.381$, with the level of significance, $p=0.713$. This value exceed the threshold value of 0.05 ( $p>0.05)$, hence null hypothesis (H03) is accepted where there is no significant difference between Malaysian and Indonesian trainee teachers' perception on the effectiveness of international teaching practice program from the aspects of attitude.

\section{T-Test Analysis for Research Question 4}

Table 7. T-test analysis on the effectiveness of international teaching practice program from the aspect of knowledge content based on the trainee teachers

\begin{tabular}{cccccc}
\hline Trainee Teacher & Total & Mean & Standard Deviation & T-value & Significance Level \\
\hline Malaysia & 35 & 4.178 & 0.926 & 0.479 & 0.645 \\
Indonesia & 35 & 4.148 & 0.105 & & \\
\hline
\end{tabular}

The hypothesis is as follows:

H04: There is no significant difference between Malaysian and Indonesian trainee teachers' perception on the effectiveness of international teaching practice program from the aspects of knowledge content

Table 7 shows that the $\mathrm{t}$-value for the comparison of attitude aspect between Malaysian and Indonesian trainee teachers in international teaching practice is $\mathrm{t}=0.479$, with the level of significance, $\mathrm{p}=0.645$. This value exceed the threshold value of 0.05 ( $p>0.05)$, hence null hypothesis (H04) is accepted where there is no significant difference between Malaysian and Indonesian trainee teachers' perception on the effectiveness of international teaching practice program from the aspects of knowledge content.

\section{CONCLUSION}

Research Question 1: The Effectiveness of International Teaching Practice Program on Malaysian And Indonesian Trainee Teachers from the Aspect of Generic Skills

The main focus for this research question is in determining the effectiveness of international teaching practice program on the trainee teachers from the aspect of generic skills including communication skills, team working skills, and problem solving skill. Overall, the trainee teachers have the opinion that the international teaching practice program has an impact to Malaysia and Indonesian trainee teachers with the mean score of 4.14 and 4.08 , respectively. It shows that the effectiveness of international teaching practice program on the aspect of generic skills is high.

\section{The effectiveness of international teaching practice program on Malaysian and Indonesian trainee teachers from the aspect of communication skills}

This research question was tested using t-test analysis to test the perception of Malaysian and Indonesian trainee teachers on the effectiveness of international teaching practice program from the aspect of communication skills. The t-test analysis shows that there is no significant difference $(\mathrm{p}=$ 0.790) between Malaysian and Indonesian trainee teachers' perception on the effectiveness of international teaching practice program from the aspect of communication skills. Respondents from both countries have the same perception that they had successfully enhanced their communication skills throughout the entire teaching practice program. The mean for other items also influenced the value of t-test conducted.

For example, the communication skills of Malaysian $($ mean $=4.10)$ and Indonesian $($ mean $=4.12)$ trainee teachers is high, showing that the communication skill has been acquired with no significant difference between the trainee teachers from both countries. This is because, the trainee teachers from Malaysia $($ mean $=4.31)$ and Indonesia (mean $=4.22)$ had successfully drawn the students' attention using questioning method, showing a positive feedback from the student. Simultaneously, they had created the two-way interaction (active learning) between them and the students which increase the confidence level of the students towards the teacher and the subject being taught. 
The results also show that the respondents had acquired high communication skills by using the question and answer method to create the students' involvement in class as supported by Abdullah and Ainon (2005) which stated that teachers could interact with the students through talking, explaining, questioning, discussing, and giving advice. The questioning method used in teaching and learning process helps the student in synthesising the information to answer the question asked. Teachers are able to analyse the students' level of understanding in their class and further improve their teaching method.

Even though the overall mean is high with no significant difference recorded, there's still a few items with medium mean recorded. In delivering the good and clear teaching and learning session, Malaysian trainee teachers recorded a medium mean of 3.60 while Indonesian trainee teachers recorded medium high mean of 3.91. A clear delivering during the teaching and learning process ease the student understanding on the subject being taught. The trainee teachers have shown able to deliver the teaching clearly during the teaching practice at school. As supported by Mok (2000), loud and clear intonation and pronunciation is needed to deliver a good teaching and learning session. Hence, Malaysia trainee teachers need more time to suit themselves with the new environment. Furthermore, the language barrier is another factor that the Malaysian trainee teachers faced during the program.

\section{The effectiveness of international teaching practice program on Malaysian and Indonesian trainee teachers from the aspect of team working skills}

This research question was tested using t-test analysis to test the perception of Malaysian and Indonesian trainee teachers on the effectiveness of international teaching practice program from the aspect of team working skills. The t-test analysis shows that there is no significant difference $(p=$ 0.822) between Malaysian and Indonesian trainee teachers' perception on the effectiveness of international teaching practice program from the aspect of team working skills. Respondents from Malaysia (mean $=4.24)$ and Indonesia $($ mean $=4.22$ ) have the same perception that they had successfully enhanced their team working skills throughout the entire teaching practice program.

The results show that the commitment of both Malaysian $($ mean $=4.37)$ and Indonesian $($ mean $=4.45)$ trainee teachers improved after they had a discussion with their adviser. Respondents from both countries able to improve their team working skills which helped them with their teaching. Team working has many benefits to the individual in the team, as well as to the whole team itself. It helps in increasing work productivity and quality. Hence, a satisfying work can be produced by the shared idea in a group. This item also supported that there is no significant difference between the perception of the trainee teachers from both countries.

In addition, Malaysian trainee teachers $($ mean $=4.37)$ and Indonesian trainee teachers $($ mean $=4.34)$ show that they mostly agree to work together with other teachers in the school to complete the task given during the teaching practice program. It is one of the item which supports that there is no significant difference between the perception of trainee teachers from both countries. They successfully implemented the team working skill during the program. As supported by Yusof and Bibi (2007), one of the criteria in team working is that the members help each other, contributing their each expertise and skills actively in completing the task given.

\section{The effectiveness of international teaching practice program on Malaysian and Indonesian trainee teachers from the aspect of problem solving skills}

This research question was tested using t-test analysis to test the significance relationship of Malaysian and Indonesian trainee teachers' perception on the effectiveness of international teaching practice program from the aspect of problem solving skills. The t-test analysis shows that there is no significant difference $(\mathrm{p}=0.178)$ between Malaysian and Indonesian trainee teachers' perception on the effectiveness of international teaching practice program from the aspect of problem solving skills. Respondents from Malaysia $($ mean $=4.09)$ and Indonesia $($ mean $=3.91)$ have high and effective problem solving skill, and they have the same perception on the effectiveness of the international 
teaching practice program. However, the mean recorded by this skill is the lowest among other generic skills tested in this study.

Overall, the respondents from Malaysia (mean $=3.77$ ) and Indonesia (mean 3.89) has high skills in helping the students to solve the problem with the subject being taught. They realised that a little help from the teachers could help the students in generating idea to solve the problem given to them. It is the role of the teacher to share the problem with the students during teaching and learning process, which at the same time could help the teacher solve the problem in teaching. The mean recorded is lower than other items due to the difference in culture and they need more time to blend themselves in. However, this item still supported that there is no significant difference between the perception of trainee teachers from both countries.

The findings also show that Malaysian trainee teachers $($ mean $=3.77)$ have intermediate problem solving skill in solving a problem without the help from their adviser. They are not able to solve the problem among themselves. The same goes with Indonesian trainee teachers (mean 3.71), which also have intermediate problem solving skills. This is partly because of the difference in content and language which require the teachers to solve the problem of language barrier. Nevertheless, since they are in different country, they might have acted differently when teach at their own country. The item still supported that there is no significant difference between the perception of trainee teachers from both countries.

\section{Research question 2: The effectiveness of international teaching practice program on Malaysia and Indonesian trainee teachers from the aspect of lesson plan}

This research question was tested using t-test analysis to test the significance relationship of Malaysian and Indonesian trainee teachers' perception on the effectiveness of international teaching practice program from the aspect of lesson plan. The t-test analysis shows that there is no significant difference $(\mathrm{p}=0.841)$ between Malaysian and Indonesian trainee teachers' perception on the effectiveness of international teaching practice program from the aspect of lesson plan. Respondents from Malaysia $($ mean $=4.09)$ and Indonesia $($ mean $=4.14)$ have high and effective lesson plan during the teaching practice program, and they have the same perception on the effectiveness of the international teaching practice program.

From the results obtained, both Malaysian $($ mean $=4.29)$ and Indonesian $($ mean $=4.31)$ had received a good response from the students during the teaching and learning process. This item also supported that there is no significant difference between the perception of Malaysian and Indonesian trainee teachers on the effectiveness of international teaching practice program from the aspect of lesson plan. Other items were analysed where the overall result shows that the respondents from both countries (Malaysian, mean $=4.09$, Indonesian, mean $=4.03$ ) agree that teaching aid could save a good amount of time during the teaching and learning process. This is because, the teaching aid ease the process of explaining complex concept of knowledge, where the students can easily understand the concept. 86.8\% of the respondents in Adzman (2003) agree that teaching aid helps the teaching and learning process. Both means recorded still supported that there is no significant difference between the perception of Malaysian and Indonesian trainee teachers on the effectiveness of international teaching practice program from the aspect of lesson plan.

Malaysian $($ mean $=4.06)$ and Indonesian $($ mean $=4.06)$ trainee teachers are able to control the environment in class. Again, there is no significant difference between the perception of Malaysian and Indonesian trainee teachers. A good environment influence the teaching and learning process in class. If the environment is not well organised by the teacher, the teaching and learning session will not be effective. Hence, lesson plan is essential in making sure that the teaching and learning process took place in a good environment effectively. A psychological study also proved that the environment affects students' behaviour, where the school climate motivates the environment and helps the students to achieve higher grades. 


\section{Research question 3: The effectiveness of international teaching practice program on Malaysia and Indonesian trainee teachers from the aspect of attitude}

This research question was tested using t-test analysis to test the significance relationship of Malaysian and Indonesian trainee teachers' perception on the effectiveness of international teaching practice program from the aspect of attitude. The t-test analysis shows that there is no significant difference ( $p$ $=0.713$ ) between Malaysian and Indonesian trainee teachers' perception on the effectiveness of international teaching practice program from the aspect of attitude. Respondents from Malaysia (mean $=4.12$ ) and Indonesia (mean $=4.16$ ) exhibited excellent attitude during the teaching practice program, and they have the same perception on the effectiveness of the international teaching practice program. The result obtained also shows that Indonesian trainee teachers $($ mean $=4.42)$ incorporate well with the teachers and staffs at the school, and they blended well with the society. The mean recorded shows a positive influence on the overall mean for the aspect of attitude.

The results show that Malaysian $($ mean $=4.28)$ and Indonesian $($ mean $=4.22)$ trainee teachers have high confidence level during the teaching and learning process. Both means show that there is no significant difference between the perceptions of trainee teachers from both countries. The confidence level among trainee teachers helps the students to focus on what being delivered in class. The different environment factor boost the trainee teachers' spirit to deliver well even with the language barrier. Confidence level is essential among new teachers, as they need to be confidence to deliver an effective teaching and learning process.

\section{Research question 4: The effectiveness of international teaching practice program on Malaysia and Indonesian trainee teachers from the aspect of knowledge}

This research question was tested using t-test analysis to test the significance relationship of Malaysian and Indonesian trainee teachers' perception on the effectiveness of international teaching practice program from the aspect of knowledge. The t-test analysis shows that there is no significant difference $(\mathrm{p}=0.645)$ between Malaysian and Indonesian trainee teachers' perception on the effectiveness of international teaching practice program from the aspect of knowledge. Respondents from Malaysia $($ mean $=4.18)$ and Indonesia $($ mean $=4.15)$ possessed high knowledge during the teaching practice program, and they have the same perception on the effectiveness of the international teaching practice program. Most of the trainee teachers are proficient with the knowledge on the subject they have to teach. Knowledge from the perspective of teaching helps the teachers in playing an effective role to solve the problem during class.

The results obtained show that Malaysian trainee teachers $($ mean $=4.29)$ agree that various examples given to the students during class will help the students to understand the concept easily and effectively. The results obtained from Malaysian trainee teachers $($ mean $=4.31)$ also show that they could match the content of the subject with the students ability. It shows that the respondents are able to master well the knowledge content and able to identify the student's ability.

It is essential to identify the student's ability, as students from different class have different level of ability. The trainee teachers need to match the content of the subject in-line with the ability of the students for an effective teaching and learning process. At the same time, it will help in ensuring a good and positive feedback from the students. This is proven by the results obtained by Malaysian $($ mean $=4.06)$ and Indonesian $($ mean $=4.14)$ trainee teachers, where they are able to correlate between the environment and the teaching process. They understood well the concept of teaching and learning. It is essential to fully understand the concept of the subject delivered so that the students can easily understand the subject being taught. The environment can be a tool to correlate the concept and idea with daily activities so that the students can apply the knowledge well in their lives. The results also show that there is no significant difference between Malaysian and Indonesian trainee teachers' perception on the effectiveness of international teaching practice program.

\section{REFERENCES}

Submit Date: 05.07. 2018, Acceptance Date: 26.08.2018, DOI NO: 10.7456/1080SSE/121

Research Article - This article was checked by Turnitin

Copyright (C) The Turkish Online Journal of Design, Art and Communication 
Abdullah, H., \& Ainon, M. (2005). Kemahiran interpersonal untuk guru. PTS Publications and Distributors Sdn. Bhd.

Adzman, M. J. (2003). Penggunaan ABM di dalam proses pengajaran dan pembelajaran mata pelajaran, Kemahiran Hidup di sekolah menengah, Seremban Timur, Seremban Negeri Sembilan. Degree thesis, Universiti Teknologi Malaysia.

Ahmad, N. B. (2010). Kesediaan penerapan kemahiran generik guru-guru pelatih teknikal semasa latihan mengajar. Degree thesis, Universiti Teknologi Malaysia.

Krejcie, R. V., \& Morgan, D. W. (1970). Determining sample size for research activities. Educational and Psychological Measurement, 30(3), 607-610.

Mohd, N. A. G. (2003). Reka bentuk tinjauan soal selidik pendidikan. Universiti Teknologi Malaysia Press.

Mok, S. S. (2000). Ilmu pendidikan untuk KPLI. Kumpulan Budiman.

Yusof, B., \& Bibi, S. H. K. (2007). Kerja berpasukan dalam kalangan guru Sekolah Kebangsaan Parit Setongkat Muar. Universiti Teknologi Malaysia. 